Abstracted/indexed in Academic Search Complete, Agroforestry Abstracts, Asia Journals Online, Bangladesh Journals Online, Biological Abstracts, BIOSIS Previews, CAB Abstracts, Current Abstracts, Directory of Open Access Journals, EMBASE/Excerpta Medica, Google Scholar, HINARI (WHO), International Pharmaceutical Abstracts, Open J-gate, Science Citation Index Expanded and Social Sciences Citation Index

\title{
Two isomeric compounds from Streptomyces species and their antimicrobial activity
}

\author{
Zakia Sultana Sathi', Md. Anwar Habib², Abu Syed Md. Anisuzzaman³ and Md. Anwarul \\ Islam 3 \\ ${ }^{1}$ Department of Pharmacy, Daffodil International University, Dhaka; ${ }^{2}$ Department of Pharmacology, Rajshahi \\ Medical College, Rajshahi 6000; ${ }^{3}$ Department of Pharmacy, University of Rajshahi, Rajshahi 6205, Bangladesh.
}

\begin{tabular}{|lr|}
\hline \multicolumn{2}{|l|}{ Article Info } \\
\hline Received: & 3 June 2010 \\
Accepted: & 17 July 2010 \\
Available Online: & 28 September 2010 \\
DOI: $10.3329 /$ bjp.v5i1.5188 \\
Cite this article: \\
Sathi ZS, Habib & MA, Anisuzzaman \\
ASM, Islam MA. Two isomeric com- \\
pounds from Streptomyces species and \\
their antimicrobial activity. Bangla- \\
desh J Pharmacol. 2010; 5: 68-72.
\end{tabular}

\section{Abstract}

The chloroform extract of the culture filtrate of an isolated Streptomyces species upon chromatographic analysis had lead to the isolation of two isomeric compounds (I and II). The structure of the compounds was considered to be Stretomysone A (I) and Streptomysone B (II) by its spectral data. Both the compounds showed significant antimicrobial activity against tested pathogenic bacteria and fungus. The compounds seem to be first report of isomeric compound from Streptomyces species having antimicrobial activity.

\section{Introduction}

Microbial natural products still appear as the most promising source of the future antibiotics that society is expecting (Pelaez, 2006). Since the isolation of actinomycin in 1940 and streptomycin in 1944 by Waksman (Waksman and Woodruff, 1940; Schatz et al., 1944), the Actinomycetes have received tremendous attention of the scientists. Members of Streptomyces are a rich source of bioactive compounds, notably antibiotics, enzymes, enzyme inhibitors and pharmacologically active agents (Kazuki et al., 2005). About 75\% of the known commercially and medically useful antibiotics are produced by Streptomyces (Sujatha et al., 2005). Waksman (Waksman, 1959) recognized the natural substrates that are ideal sources for the isolation of Actinomycetes. Among these, they are quite commonly found in soil, water and other environments (Ghanem et al., 2000). Owing to indiscriminate use of antibiotics and for various reasons the bacteria and other microorganisms are gaining resistance to the presently available antibiotics and pose a serious threat to the existence of human. Hence the search of new and more efficient antibiotics is a pressing need to time. As a part of our continuing studies of metabolites produced by microorganisms obtained soil samples collected throughout Bangladesh (Anisuzzaman, 2000), we isolated Streptomyces from soil sample and report herein the isolation of two isomeric compounds from the Streptomyces species and their antimicrobial activity.

\section{Materials and Methods \\ Collection of organism}

The organism was isolated from the soil sample, collected from the district of Pabna, Bangladesh at the depth of 0.5 meter using "crowded plate technique". The organism was identified as Streptomyces species (Anisuzzaman, 2000) by morphological and biochemical studies (Holt et al., 1994; Williams et al., 1983).

\section{Production, isolation and purification of compounds}

The organism was allowed to grow in a number of culture flasks of $500 \mathrm{~mL}$ capacity containing Czapek- 
Dox broth alkaline medium at $37.5^{\circ} \mathrm{C}$. The broth was separated from the mycelial mat on $8^{\text {th }}$ day to get the maximum yield of antibacterial activity. The culture filtrate then subjected to repeated chloroform extraction and the extract was evaporated under reduced pressure. The crude antibiotic fraction was resolved by thin layer chromatography (TLC), preparative TLC (Stahl, 1969) using the solvent system, n-hexane, chloroform and methanol in a ratio of 7:5:1 (Stahl, 1969) and obtained on large scale on column chromatography (Beckett et al., 1986). For checking purity of the compound TLC was carried out using pre-coated silica gel 60 F254 plates (Merck) and detection was made by visualization under UV light $(254 \mathrm{~nm})$ and spraying with $0.1 \%$ vanillin sulfate spray reagent followed by heating.

\section{Spectral measurement}

UV spectra were recorded on a Beckman double beam spectrometer. IR spectra were obtained by a Perkin Elemer 1600 FTIR spectrometer. ${ }^{1} \mathrm{H}-(500 \mathrm{MHz})$ and ${ }^{13} \mathrm{C}$ (125 MHz) spectra were acquired on a JEOL JNM alpha spectrometer using TMS as internal standard.

\section{Antimicrobial screening}

Antimicrobial compound I and II ( 25 and 50 qg per disc, respectively) were determined against four Gram positive and five Gram negative bacteria, and four pathogenic fungus by standard disc diffusion method (Masako et al., 2004; Bauer et al., 1996). Amoxicillin disc (25 qg per disc) and griseofulvin (20 qg per disc) were used as standard for the comparison of antimicrobial activity for the bacteria and fungus, respectively. The test organisms were collected from the Department of Microbiology, University of Dhaka and antimicrobial activity was conducted at the Department of Pharmacy, Daffodil International University, Dhaka.

The minimum inhibitory concentration (MIC) values of the compounds were determined against Gram positive (Bacillus subtilis, Streptococcus- $\beta$-hemolyticus) and Gram negative (Escherichia coli, Shigella dyscenteriae and Salmonella typhii $A)$ bacteria $\left(10^{7}\right.$ cells $\left./ \mathrm{mL}\right)$ by serial dilution technique (Reiner, 1982) in nutrient broth media.

\section{Results and Discussion}

The chloroform extract of the culture filtrate after resolution by conventional thin layer chromatographic technique yielded two compounds designed as I and II having $\mathrm{Rf}$ value 0.60 and 0.65 , respectively in solvent system $\mathrm{CHCl}_{3}: \mathrm{CH}_{3} \mathrm{OH}(10: 1)$. Both the compounds were crystalline and soluble in chloroform, ethyl acetate and methanol. Their structure was elucidated from the UV, IR, 1H-NMR, 13C-NMR and comparing the 13CNMR spectrum with the compounds, monocillinols 1 and 2 (Biswas et al., 2000).
Compound I: In UV spectrum, the strong absorption band at $209 \mathrm{~nm}$ indicated the presence of unsaturation. The IR spectrum revealed that the absorption band at $1760 \mathrm{~cm}-1$ and $1420 \mathrm{~cm}-1$ which demonstrative of carbonyl group $(>\mathrm{C}=\mathrm{O})$ in six membered lactone ring and $>\mathrm{C}=\mathrm{C}<$ stretching in aromatic compound, respectively. While the absorption band at $1000 \mathrm{~cm}-1$ and 1210 $\mathrm{cm}-1$ are indicative of $\mathrm{C}-\mathrm{N}$ and $>\mathrm{C}=\mathrm{O}$ stretching and $820 \mathrm{~cm}-1$ for C-H stretching (Pavia et al., 1979).

The 1H-NMR spectrum exhibited signals for two aromatic olefenic proton at $\delta 8.8(1 \mathrm{H}, \mathrm{d}$ like $)$ and 5.9 $(1 \mathrm{H}, \mathrm{m}$ like), two methine proton at $\delta 8.5(1 \mathrm{H}, \mathrm{d}$ like $)$ and $4.93(1 \mathrm{H}, \mathrm{d}$ like), two methylene proton in cyclic system at $\delta 8.79(1 \mathrm{H}, \mathrm{m})$ and $2.7(1 \mathrm{H}, \mathrm{m})$ and two methine proton at $\delta 2.51(1 \mathrm{H}, \mathrm{m})$ and $2.0(1 \mathrm{H}, \mathrm{m})$. The spectrum also showed signals for two methoxy methyl proton at $\delta 2.1(3 \mathrm{H}, \mathrm{s})$ and $1.96(3 \mathrm{H}, \mathrm{s})$. In addition for tertiary methyl, secondary methyl and primary methyl proton signal at $\delta 0.95(3 \mathrm{H}, \mathrm{s}) 1.18(3 \mathrm{H}, \mathrm{d}$ like $)$ and 1.3 $(3 \mathrm{H}, \mathrm{s}$ like), respectively were also evident.

The 13C-NMR spectrum (Table I) of the compound I exhibited signals for three carbonyl carbon at $\delta$ 179.0, 172.77 and 168.0, a signal for a double bonded carbon attached with oxygen at $\delta 157.1$, for two olefenic carbon at 132.9 and at $\delta 127.0$, for olefinic tertiary carbon at $\delta$ 130.0 and two omethoxy carbon at $\delta 52.02$ and 49.39, for tertiary carbon attached with electronegative atom or group at $\delta 47.18$, for methylene group in cyclic ring system at $\delta 38.12$ and for carbon attached with oxygen at $\delta$ 66.0.

From the IR and NMR spectra, the compound I was supposed to contained groups: One six-membered lactone ring, two methoxy group, two methyl group, two methylene group, three carbonyl group and two methene group.

Comparison of the 13C-NMR spectrum revealed that the compound I those of monocillinol 1 and was similar to those except at C-2 (157.1), C-5 (47.18) and C-6 (76.39). In addition compound I contained signals at $\delta$ 49.39 for $\mathrm{OCH}_{3}, 20.48$ for $\mathrm{CH}_{3}$ and at $168,47.18$ \& 20.67 for $\left(>\mathrm{COCH}_{2}-\mathrm{CH}_{3}\right)$, respectively.

The shift of signal 58.1 to 47.18 at C-5 of monocillinol 1 could be explained by the presence of methyl group attached at C-5 position. Again the attachment of methyl group at C-13 could be explained considering the shift of signal from 98.7 to 127.0. The remaining signals $-\mathrm{CO}-\mathrm{CH}_{2}-\mathrm{CH}_{3}$ and $-\mathrm{OCH}_{3}$ were could assign at position 4 and 19 respectively.

Compound II: In UV spectrum, the strong absorption band at $215 \mathrm{~nm}$ indicates the presence of unsaturation. In IR spectrum, the absorption band at $1750 \mathrm{~cm}-1$ and $1470 \mathrm{~cm}-1$ are characteristics of carbonyl group $(>C=\mathrm{O})$ of six membered lactone ring and $>\mathrm{C}=\mathrm{C}<$ stretching in aromatic compound, respectively. The absorption band 
Table I

\section{${ }^{1} \mathrm{H}-\mathrm{NMR}$ and ${ }^{13} \mathrm{C}-\mathrm{NMR}$ spectral data $\left(500 \mathrm{MHz} \mathrm{CDCl}_{3}\right)$ for compound I and II $\left.\mathrm{CDCl}_{3}\right)$ for compound I and II}

\begin{tabular}{|c|c|c|c|c|}
\hline \multirow{2}{*}{$\begin{array}{l}\text { Position of } \\
\text { carbon }\end{array}$} & \multicolumn{4}{|c|}{${ }^{13} \mathrm{C}-\mathrm{NMR}$ of 5 in ppm } \\
\hline & Monocillinol 1 & Streptomysone A (I) & Monocillinol 2 & Streptomysone B (II) \\
\hline 1 & - & - & - & - \\
\hline 2 & 157.1 & 153.0 & - & - \\
\hline 3 & 168.8 & 172.8 & - & - \\
\hline 4 & - & - & - & - \\
\hline 5 & 58.1 & 47.2 & 59.0 & 46.5 \\
\hline 6 & 75.7 & 76.9 & 76.7 & 70.8 \\
\hline 7 & 134.4 & 132.9 & 127.5 & 127.0 \\
\hline 8 & 130.9 & 130.0 & 141.1 & 147.6 \\
\hline 9 & 35.0 & 38.1 & 30.2 & 29.6 \\
\hline 10 & 67.0 & 66.0 & 72.6 & 73.7 \\
\hline 11 & 166.0 & 168.0 & 166.3 & 170.1 \\
\hline 12 & 52.1 & 52.0 & 51.9 & 52.6 \\
\hline 13 & 98.7 & 127.0 & 98.5 & 122.0 \\
\hline 14 & - & 20.5 & - & 20.5 \\
\hline 15 & - & 179.0 & - & 179.0 \\
\hline 16 & - & 17.2 & - & 47.2 \\
\hline 17 & - & 20.7 & - & 20.7 \\
\hline 18 & - & 13.1 & 1.0 & 17.7 \\
\hline 19 & - & 49.4 & 2.0 & 49.4 \\
\hline
\end{tabular}
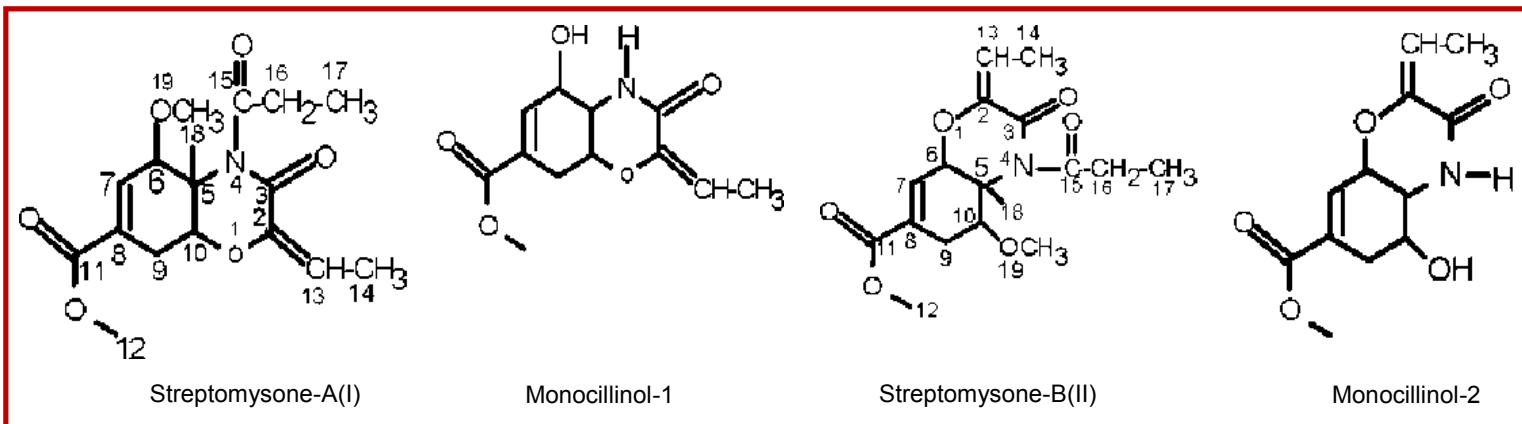

at $1260 \mathrm{~cm}-1$ and $1300 \mathrm{~cm}-1$ are indicative of $\mathrm{C}-\mathrm{N}$ and $>\mathrm{C}=\mathrm{O}$ stretching and at $820 \mathrm{~cm}-1$ for $\mathrm{C}-\mathrm{H}$ stretching (Pavia et al., 1979).

In 1H-NMR spectrum, the signals at $\delta 8.76(1 \mathrm{H}, \mathrm{d}$ like $)$ and $5.86(1 \mathrm{H}, \mathrm{m}$ like) may be attributed to two aromatic olefinic proton. The signals at $\delta 8.52(1 \mathrm{H}, \mathrm{d}$ like $)$ and $4.93(1 \mathrm{H}, \mathrm{d}$ like) may be due to two methine proton. The proton signals at $\delta 8.79(1 \mathrm{H}, \mathrm{m})$ and $2.7(1 \mathrm{H}, \mathrm{m})$ may be ascrible to two methylene proton in cyclic system and at $\delta 2.51(1 \mathrm{H}, \mathrm{m})$ and $2.0(1 \mathrm{H}, \mathrm{m})$ may be due to two methine proton. The proton signals at $\delta 2.1(3 \mathrm{H}, \mathrm{s})$ and $1.96(3 \mathrm{H}, \mathrm{s})$ may be due to two methoxy methyl proton. The proton signals at $\delta 0.95(3 \mathrm{H}, \mathrm{s}) 1.18(3 \mathrm{H}, \mathrm{d}$ like $)$ and $1.3(3 \mathrm{H}, \mathrm{s}$ like) may be due to tertiary methyl, secondary methyl and primary methyl proton, respectively.

In ${ }^{13} \mathrm{C}-\mathrm{NMR}$ spectrum (Table I) the compound II exhibited signal at $\delta 122$ which may be due to the double bonded carbon attached with oxygen. The carbon signals at $\delta 127.0$ for olefinic carbon and $\delta 147.64$ for olefinic carbon attached with carbon containing oxygen. The signals at $\delta 52.61$ and 49.31 for two omethoxy carbon, at $\delta 46.54$ for tertiary carbon and at $\delta 39.64$ for methelene carbon in cyclic system. Carbon signal at $\delta$ 73.73 for metheine carbon attached with oxygen and at $\delta 47.18$ for methelene carbon.

From the IR and NMR spectra, the compound II is supposed to contain the following groups: One six 


\begin{tabular}{|c|c|c|c|c|c|}
\hline \multicolumn{6}{|c|}{ Table II } \\
\hline \multicolumn{6}{|c|}{ Antibacterial activity of the compound I and II } \\
\hline \multirow[t]{3}{*}{ Test bacteria } & \multicolumn{5}{|c|}{ Diameter of zone of inhibition (mm) } \\
\hline & \multicolumn{2}{|c|}{ Compound I } & Amoxicillin & \multicolumn{2}{|c|}{ Compound II } \\
\hline & 25 pg per disc & 50 pg per disc & $25 \mathrm{pg}$ per disc & $25 \mathrm{pg}$ per disc & $50 \mathrm{pg}$ per disc \\
\hline \multicolumn{6}{|l|}{ Gram positive } \\
\hline Bacillus subtilis & 17 & 25 & 29 & 15 & 20 \\
\hline Bacillus megatrium & 18 & 25 & 27 & 12 & 16 \\
\hline Staphylococcus aureus & 11 & 16 & 26 & 09 & 14 \\
\hline $\begin{array}{l}\text { Streptococcusf- } \\
\text { hemolyticus }\end{array}$ & 12 & 16 & 27 & 10 & 14 \\
\hline \multicolumn{6}{|l|}{ Gram negative } \\
\hline Escherichia coli & 20 & 28 & 33 & 25 & 31 \\
\hline $\begin{array}{l}\text { Pseudomonas aure- } \\
\text { ginosae }\end{array}$ & 12 & 17 & 28 & 18 & 25 \\
\hline Shigella dyscenteriae & 16 & 24 & 33 & 22 & 28 \\
\hline Salmonella typhii A & 11 & 19 & 29 & 20 & 29 \\
\hline Klebsiella sp. & 14 & 22 & 25 & 17 & 26 \\
\hline
\end{tabular}

Table III

\section{Antifungal activity of the compound I and II}

\begin{tabular}{|lccc|}
\hline Test pathogen & \multicolumn{3}{c|}{ Diameter of zone of inhibition (mm) } \\
\cline { 2 - 4 } & Compound I & Griseofulvin & Compound II \\
& $25 \mathrm{pg} / \mathrm{disc}$ & $20 \mathrm{pg} / \mathrm{disc}$ & $100 \mathrm{pg} / \mathrm{disc}$ \\
\hline Tinea pedis & 21 & 16 & 9 \\
Tinea corporis & 16 & 17 & 12 \\
Candida albicans & 13 & 15 & 9 \\
Rhizoctoni solani & 14 & 19 & 9 \\
\hline
\end{tabular}

membered lactone ring, two methoxy group, two methyl group, two methylene group, three carbonyl group and two methene group.

The ${ }^{13} \mathrm{C}-\mathrm{NMR}$ spectrum of the compound II was compared with those of monocillinol 2 and was found to vary at C-2 (157.1), C-5 (46.5) and C-6 (70.8). In addition to the presence of the following signals at $\delta 49.39$ $\left(\mathrm{OCH}_{3}\right)$ and carbon signal at $\delta 170.1,47.18$ and 20.68 for $\left(>\mathrm{CO}-\mathrm{CH}_{2}-\mathrm{CH}_{3}\right)$, respectively.

The signals of monocillinol 2 at C-5 are shifted from 59.0 to 46.5 may due to the presence of methyl group at compound II. Similarly the carbon signals at C-13 is shifted from 98.5 to 122.0 may be due to the methyl group at $\mathrm{C}-13$ position. So there is possibility of arrangement of $-\mathrm{CO}-\mathrm{CH}_{2}-\mathrm{CH}_{3}$ group with $\mathrm{N}$ (at position No. 4 , instead of its proton).

Antimicrobial activities of the compounds: Both the compounds showed significant antimicrobial activity against the test pathogens (Table II). However, the compound I exhibited strong activity against Bacillus subtilis, Escherichia coli and Klebselia species and comparatively weak activity was observed against Pseudomonas aureginosa, Salmonella typhii A and Shegella dyscenteriae. While the compound II exhibited strong activity against Gram negative than Gram positive bacteria. The compounds are also active against tested pathogenic fungus. The compound I showed promising antifungal activity compared to the standard griseofulvin (Table III).

Minimum inhibitory concentrations of the compounds: The MIC values of the compound I against Bacillus subtilis, Streptococcus- $\beta$-hemolyticus, Escherichia coli, Shigella dyscenteriae and Salmonella typhii A were 16, 32, 16,32 and $128 \mathrm{pg} / \mathrm{mL}$, respectively and that for compound II were 32, 64, 16, 16 and $32 \mathrm{pg} / \mathrm{mL}$, respectively. From the MIC values it was found that both the compounds were potent against Bacillus subtilis and 
Escherichia coli.

Though the compounds are isomer each other, their antimicrobial spectrum are quite different. Thus, the finding of this investigation would give us valuable support to search more potent antagonistic microorganism from the soil of different regions of Bangladesh.

\section{Acknowledgement}

The authors wish to thank Dr. Naoki Sugimoto, National Institute of Health Sciences, Tokyo, Japan for the spectra analysis.

\section{References}

Abe M, Ozawa Y, Uda F, Yamada Y, Morimitsu Y, Nakamura $Y$, Osawa T. Antimicrobial activities of diterpene dialdehydes, constituents from Myoga and their quantitative analysis. Biosci Biotechnol Biochem. 2004; 68: 1601-04.

Anisuzzaman ASM. Characterization and biological activities of Streptomyces species and Aspergillus fumigatus. 2000. M. Pharm thesis. Department of Pharmacy, University of Rajshahi, Bangladesh.

Bauer AW, Kirby WM, Sherris JC, Turck M. Antibiotic susceptibility testing by a standardized single disc method. Am J Clin Pathol. 1996; 45: 493-96.

Beckett AH, Stenlake JB. Chromatography. In: Practical pharmaceutical chemistry. 3rd ed. Delhi, India, 1986, 75-76.

Biswas MHU, Amin ARMR, Islam MA, Hassan CM, Krick RG, Michael RB, Lewis KP, Rashid MA. Monocillinols A and B, novel fungal metabolites from a Monocillum sp. Tetrahedron Lett. 2000; 41: 7177-80.

Stahl E. Thin layer chromatography: A handbook. 2nd ed. New York, Springer Verlag, 1969, pp 680-89. and enumeration of marine actinomycetes from seawater and sediments in Alexandria. J Gen Appl Microbiol. 2000; 46: 105 -11 .

Holt JG, Kreig NR, Sneath PHA, Staley JT, Williams ST. Bergey's manual of determinative bacteriology. $9^{\text {th }}$ ed. Baltimore, Williams and Wilkins, 1994, pp 376-81.

Pavia DL, Lampman GM, Kriz GS. Introduction of spectroscopy: A guidebook for students of organic chemistry. USA, WB Saunders, 1979, pp 13-80.

Pela'ez F. The historical delivery of antibiotics from microbial natural products: Can history repeat? Biochem Pharmacol. 2006; 71: 981-90.

Reiner R. Antibiotics: An introduction. Switzerland, Roche Scientific Service, 1982, pp 21-25.

Schatz A, Bugie E, Waksman SA. Streptomycin, a substance exhibiting antibiotic activity against gram-positive and gram -negative bacteria. Proc Soc Exp Biol Med. 1944; 55: 66-69.

Sujatha P, Bapi Raju KV, Ramana T. Studies on a new marine Streptomycete BT-408 producing polyketide antibiotic SBR-22 effective against methicillin resistant Staphylococcus aureus. Microbio Res. 2005; 160: 119-26.

Waksman SA, Woodruff HB. Bacteriostatic and bactericidal substances produced by a soil actinomyces. Proc Soc Exp Bio Med. 1940; 45: 609-14.

Waksman SA (ed). The Actinomycetes: Isolation, identification, cultivation and preservation. Baltimore, Williams and Wilkins Company, 1959, pp 17-28.

Williams ST, Goodfellow M, Wellington EMH, Vickers JC, Alderson G, Sneath PHA, Sackin MJ, Mortimer AM. A probability matrix for identification of some Streptomycetes. J Gen Microbiol. 1983; 129: 1815-30.

Yamanaka K, Oikawa H, Ogawa HO, Hosono K, Shinmachi F, Takano H, Sakuda S, Beppu T, Ueda K. Desferrioxamine E produced by Streptomyces griseus stimulates growth and development of Streptomyces tanashiensis. Microbiology 2005; 151: 2899-905.

Ghanem NB, Sabry SA, El-Sherif ZM, Abu El-Ela GA. Isolation

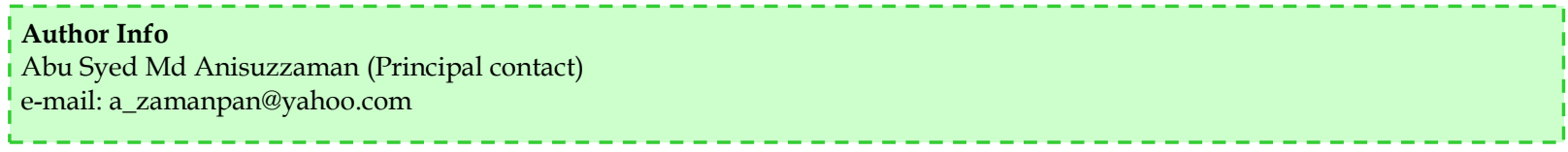

